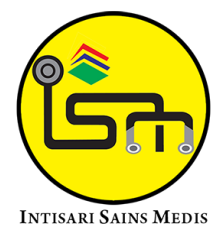

Published by Intisari Sains Medis

\title{
Efek ekstrak sambiloto (Andrographis paniculata) terhadap ekspresi matrix metalloproteinase-1 dan hipertrofi jantung pada mencit yang terpapar asap rokok
}

\author{
I Made Agus Endra Permana 1*, I Nyoman Wiryawan², Wayan Aryadana², I Gde Raka Widiana², \\ I Gusti Kamasan Nyoman Arijana ${ }^{4}$, I Made Satria Yudha Dewangga ${ }^{2}$
}

1PPDS-1 IImu Penyakit Jantung dan Pembuluh Darah, Fakultas Kedokteran, Universitas UdayanaRSUP Sanglah Denpasar, Bali, Indonesia; ${ }^{2}$ Departemen/KSM IImu Penyakit Jantung dan Pembuluh Darah, Fakultas Kedokteran, Universitas Udayana-RSUP Sanglah Denpasar, Bali, Indonesia; ${ }^{3}$ Departemen/KSM IImu Penyakit Dalam, Fakultas Kedokteran, Universitas Udayana-RSUP Sanglah Denpasar, Bali, Indonesia;

${ }^{4}$ Departemen/KSM Histologi Fakultas Kedokteran, Universitas Udayana, Denpasar, Bali, Indonesia;

\section{*Korespondensi:}

I Made Agus Endra Permana;

PPDS-1 IImu Penyakit Jantung dan Pembuluh Darah, Fakultas Kedokteran, Universitas Udayana-RSUP

Sanglah Denpasar, Bali, Indonesia;

aguscrash23@gmail.com

Diterima: 17-06-2021

Disetujui: 03-08-2021

Diterbitkan: 24-08-2021

\section{ABSTRACT}

Introduction: Sambiloto (Andrographis paniculata) is a plant that is often used in traditional medicine and is known to have antioxidant, anti-inflammatory and cardiovascular effects. There are many studies of sambiloto on inflammatory markers, but there is no study on the effect of sambiloto on MMP-1 expression. The purpose of this study was to determine the effect of sambiloto on MMP-1 expression and cardiac hypertrophy in mice exposed to cigarette smoke.

Methods: This research is an experimental analytic study with a randomized post test only control group design. Thirty-two healthy male Swiss Webster mice aged 8-10 weeks weighing 20-30 grams were divided into 4 groups, namely: control group (standard feed + exposure to cigarette smoke), P1 (standard feed + exposure to cigarette smoke + sambiloto extract 18 $\mathrm{mg} / \mathrm{kg} \mathrm{BW}$ ), P2 (standard feed + exposure to cigarette smoke + sambiloto extract $29 \mathrm{mg} / \mathrm{kg} \mathrm{BW}$ ), P3 (standard

feed + exposure to cigarette smoke + sambiloto extract $40 \mathrm{mg} / \mathrm{kg}$ BW). All groups were followed for 60 days. Results: There was a significant difference in MMP1 expression between the control group and all treatment groups. There were significant differences in MMP-1 expression between groups P1 and P2, and between $\mathrm{P} 1$ and $\mathrm{P} 3$ groups. There was a significant difference in heart weight/weight ratio between the control group and all treatment groups. There was a significant difference in the heart weight/body weight ratio between the $P 1$ and $P 3$ groups.

Conclusion: The administration of sambiloto extract decreased the expression of MMP-1 with a tendency for its effect to increase with increasing dose and the optimal dose was found in the sambiloto extract 29 $\mathrm{mg} / \mathrm{kg}$ BW. The difference in the effect of sambiloto extract on cardiac hypertrophy only appeared after the dose was increased to $40 \mathrm{mg} / \mathrm{kg} \mathrm{BW}$.

Keywords: Andrographis paniculata, cigarettes, MMP-1, cardiac hypertrophy.

Cite This Article: Permana, I.M.A.E., Wiryawan, I.N., Aryadana, W., Widiana, I.G.R., Arijana, I.G.K.N., Dewangga, I.M.S.Y. 2021. Efek ekstrak sambiloto (Andrographis paniculata) terhadap ekspresi matrix metalloproteinase-1 dan hipertrofi jantung pada mencit yang terpapar asap rokok. Intisari Sains Medis 12(2): 591-596. D0l: 10.15562/ism. v12i2.1090

\section{ABSTRAK}

Latar Belakang: Sambiloto (Andrographis paniculata) merupakan tanaman yang sering dipakai dalam pengobatan tradisional dan diketahui mempunyai efek antioksidan, anti inflamasi dan efek pada sistem kardiovaskular. Terdapat banyak penelitian sambiloto terhadap marker inflamasi, tetapi belum ada penelitian tentang efek ekstrak sambiloto terhadap ekspresi MMP-1. Tujuan dari penelitian ini untuk mengetahui efek ekstrak sambiloto terhadap ekspresi MMP-1 dan hipertrofi jantung pada mencit yang terpapar asap rokok.

Metode: Penelitian ini adalah penelitian analitik eksperimental dengan rancangan randomized post test only control group design. Tiga puluh dua mencit Swiss Webster jantan sehat berumur 8-10 minggu dengan berat 20-30 gram dibagi menjadi 4 kelompok yaitu: kelompok kontrol (pakan standar + paparan asap rokok), P1 (pakan standar + paparan asap rokok + ekstrak sambiloto $18 \mathrm{mg} / \mathrm{kg}$ BB), P2 (pakan standar + paparan asap rokok + ekstrak sambiloto $29 \mathrm{mg} / \mathrm{kg}$ BB), $\mathrm{P} 3$ (pakan standar + paparan asap rokok + ekstrak sambiloto $40 \mathrm{mg} / \mathrm{kg}$ BB). Semua kelompok diikuti selama 60 hari.

Hasil: Terdapat perbedaan signifikan ekspresi MMP1 antara kelompok kontrol dengan semua kelompok perlakuan. Terdapat perbedaan signifikan ekspresi 
MMP-1 antara kelompok P1 dengan P2, dan antara P1 dengan P3. Terdapat perbedaan signifikan rasio berat jantung/berat badan antara kelompok kontrol dengan semua kelompok perlakuan. Terdapat perbedaan signifikan rasio berat jantung/berat badan antara kelompok P1 dengan P3.
Simpulan: Pemberian ekstrak sambiloto menurunkan ekspresi MMP-1 dengan kecenderungan efeknya meningkat dengan peningkatan dosis dan dosis optimal terdapat pada ekstrak sambiloto $29 \mathrm{mg} / \mathrm{kg}$ BB. Perbedaan efek ekstrak sambiloto terhadap hipertrofi jantung baru muncul setelah dosis ditingkatkan menjadi $40 \mathrm{mg} / \mathrm{kg} B$ B.

Kata kunci: sambiloto, rokok, MMP-1, hipertrofi jantung.

Sitasi Artikel ini: Permana, I.M.A.E., Wiryawan, I.N., Aryadana, W., Widiana, I.G.R., Arijana, I.G.K.N., Dewangga, I.M.S.Y. 2021. Efek ekstrak sambiloto (Andrographis paniculata) terhadap ekspresi matrix metalloproteinase-1 dan hipertrofi jantung pada mencit yang terpapar asap rokok. Intisari Sains Medis 12(2): 591-596. D0I: 10.15562/ism. v12i2.1090

\section{LATAR BELAKANG}

Penyakit kardiovaskular

(CVD)

merupakan penyebab tersering morbiditas dan mortalitas di seluruh dunia. Organisasi kesehatan dunia (WHO) memperkirakan total 17.5 juta kematian kardiovaskular per tahun (31\% dari seluruh kematian) disebabkan karena infark miokard dan stroke. ${ }^{1}$ Faktor resiko terjadinya penyakit kardiovaskular dibagi dua yaitu faktor resiko yang tidak dapat dimodifikasi dan faktor resiko yang dapat dimodifikasi. Merokok, diabetes melitus, dislipidemia, hipertensi, obesitas, dan pola hidup kurang aktifitas merupakan faktor resiko yang dapat dimodifikasi. Sedangkan faktor resiko yang tidak dapat dimodifikasi seperti usia, jenis kelamin dan faktor genetik. ${ }^{2}$

Merokok merupakan faktor resiko mayor terjadinya CVD, dimana perokok kronik meningkatkan resiko penyakit jantung koroner (PJK) sebesar dua sampai empat kali dibandingkan bukan perokok. WHO memperkirakan sebanyak 5 juta kematian setiap tahun karena merokok aktif dan lebih dari 600 ribu kematian per tahun pada perokok pasif. Perokok pasif meningkatkan resiko penyakit jantung sebesar $25-30 \%$ dan resiko stroke sebesar 20-30\%. ${ }^{1}$ Rokok mengandung lebih dari 4720 kandungan termasuk kimiawi berbahaya seperti polycyclic aromatic hydrocarbons, radikal bebas dan gas oksidatif. Efek samping rokok terhadap kardiovaskular antara lain disfungsi vaskular, merusak fungsi endotel dan platelet, dan mempengaruhi profil lipid. Inflamasi merupakan mekanisme penting dalam pembentukan dan perkembangan aterosklerosis. ${ }^{3}$ Matrix metalloproteinase-1 (MMP-1) merupakan salah satu dari sedikit protease yang mampu mengurai kolagen fibrillar pada dinding pembuluh darah (tipe I dan III) dan juga berperan terhadap inflamasi melalui proses sitokin dan reseptor. $^{4}$ Komponen rokok yaitu acrolein berperan terhadap penyakit kardiovaskular melalui peningkatan MMP-1 dan menurunkan sekresi Biology of Tissue Inhibitor of Metalloproteinase 3 (TIMP-3) pada endotel, sehingga menghambat angiogenesis, disrupsi matriks, dan injuri pembuluh darah. ${ }^{5}$

Paparan asap rokok menyebabkan perubahan pada fungsi dan struktur kardiovaskular. Salah satunya dapat terjadi remodeling jantung atau ventrikel yang dikarakteristikkan dengan kelainan molekuler, seluler, dan interstitial sehingga terjadi perubahan ukuran, berat, geometri dan fungsi jantung. Paparan rokok menyebabkan pembesaran jantung kiri, hipertrofi miokardium, dan disfungsi ventrikel. Mekanisme yang berperan antara lain perubahan hemodinamik dan neurohormonal, stres oksidatif, inflamasi, bioavailabilitas nitric oxide (NO), matrix metalloproteinase dan aktivasi mitogenactivated protein kinase. $^{6}$ Paparan asap rokok pada tikus selama 1 bulan dapat meyebabkan hipertrofi jantung, inflamasi, pro fibrotik dan peningkatan marker aterogenik dan kalsifikasi aorta. Pemberian antioksidan dapat mencegah hipertrofi jantung dan menurunkan kadar marker aterosklerosis yang disebabkan paparan rokok. $^{7}$

Sambiloto (Andrographis paniculata) merupakan tanaman yang telah lama digunakan pada pengobatan tradisional di Asia. Kandungan sambiloto (andrographolide) mempunyai efek antioksidan, antiinflamasi dan efek pada sistem kardiovaskular. Beberapa studi menunjukkan efek anti-aterosklerosis sambiloto dimana dapat memperbaiki inflamasi dan efek hipolipidemik potent dengan menurunkan kadar kolesterol total, trigliserida, high density lipoprotein cholesterol (HDL), dan low density lipoprotein cholesterol (LDL). ${ }^{8}$ Walaupun demikian belum terdapat penelitian tentang efek ekstrak sambiloto terhadap ekspresi matrix metalloproteinase-1 (MMP-1) dan hipertrofi jantung. Berdasarkan uraian di atas maka akan dilakukan penelitian mengenai efek pemberian ekstrak sambiloto (Andrographis paniculata) terhadap ekspresi matrix metalloproteinase-1 dan hipertrofi jantung pada mencit yang terpapar asap rokok

\section{METODE}

Penelitian analitik eksperimental ini mengadopsi rancangan randomized post test only control group design. Penelitian dilaksanakan pada bulan Oktober 2020 sampai dengan Januari 2021. Pembuatan ekstrak sambiloto dilaksanakan di Laboratorium Biologi, Fakultas Farmasi, Universitas Udayana. Pemeliharaan mencit dan pemeriksaan ekspresi MMP1 dilakukan di Lab Biomedik Terpadu bagian histologi Fakultas Kedokteran Universitas Udayana.

Total sampel penelitian adalah 32 ekor mencit Swiss Webster jantan sehat berumur 8-10 minggu dengan berat 20- 
30 gram yang diambil secara acak dari populasi mencit Swiss Webster yang terpapar asap rokok di Lab Biomedik Terpadu, Universitas Udayana. Semua sampel mencit terlebih dahulu diadaptasi selama tujuh hari. Sampel dibagi menjadi 4 kelompok diantaranya satu kelompok kontrol dan tiga kelompok perlakuan. Kelompok kontrol mendapatkan pakan standar dan paparan asap rokok. Kelompok perlakuan 1 diberikan pakan standar, paparan asap rokok dan ekstrak sambiloto dosis $18 \mathrm{mg} / \mathrm{kg}$ BB. Kelompok perlakuan 2 diberikan pakan standar, paparan asap rokok dan ekstrak sambiloto dosis $29 \mathrm{mg} / \mathrm{kg}$ BB. Kelompok perlakuan 3 diberikan pakan standar, paparan asap rokok dan ekstrak sambiloto dosis $40 \mathrm{mg}$ / kg BB.

Mencit dipelihara dalam kandang secara berkelompok, sebanyak 8 ekor mencit per kandang. Kandang terbuat dari bak plastik berukuran $30 \times 20 \times 20$ $\mathrm{cm}$ dengan alas sekam untuk menyerap kotoran mencit dan pada bagian atas diberi tutup dari anyaman kawat. Kandang ditempatkan dalam ruangan berventilasi dan udara alami. Pada hari ke 61 mencit dikorbankan untuk diperiksa ekspresi MMP-1 pada aorta ascenden dan mengukur rasio berat jantung/berat badan mencit.

Pemaparan asap rokok dilakukan dengan memasukkan 8 ekor mencit ke dalam smoking chamber kemudian rokok dipasang pada pipa yang dihubungkan dengan pompa udara. Rokok yang digunakan adalah rokok kretek dengan kandungan nikotin 2,2 $\mathrm{mg}$ dan tar $31 \mathrm{mg}$. Rokok yang telah dipasang kemudian dibakar, selanjutnya pompa udara dinyalakan, bersamaan dengan itu oksigen juga dialirkan kedalam smoking chamber dengan kecepatan 0,5 ppm. Perlakuan pemaparan dilakukan dengan menggunakan 2 batang rokok selama 3040 menit dan dilakukan dua kali setiap hari (pukul 09.00 dan 14.00 wita), selama 60 hari. Pemaparan ini dilakukan kepada semua kelompok.

Prosedur pemeriksaan MMP-1 dimulai dari pembuatan sediaan histopatologis yang terdiri dari beberapa tahap yaitu fiksasi, dehidrasi, clearing, embedding, dan pemotongan. Pengecatan enzim MMP-1 mempergunakan Kit MMP-1

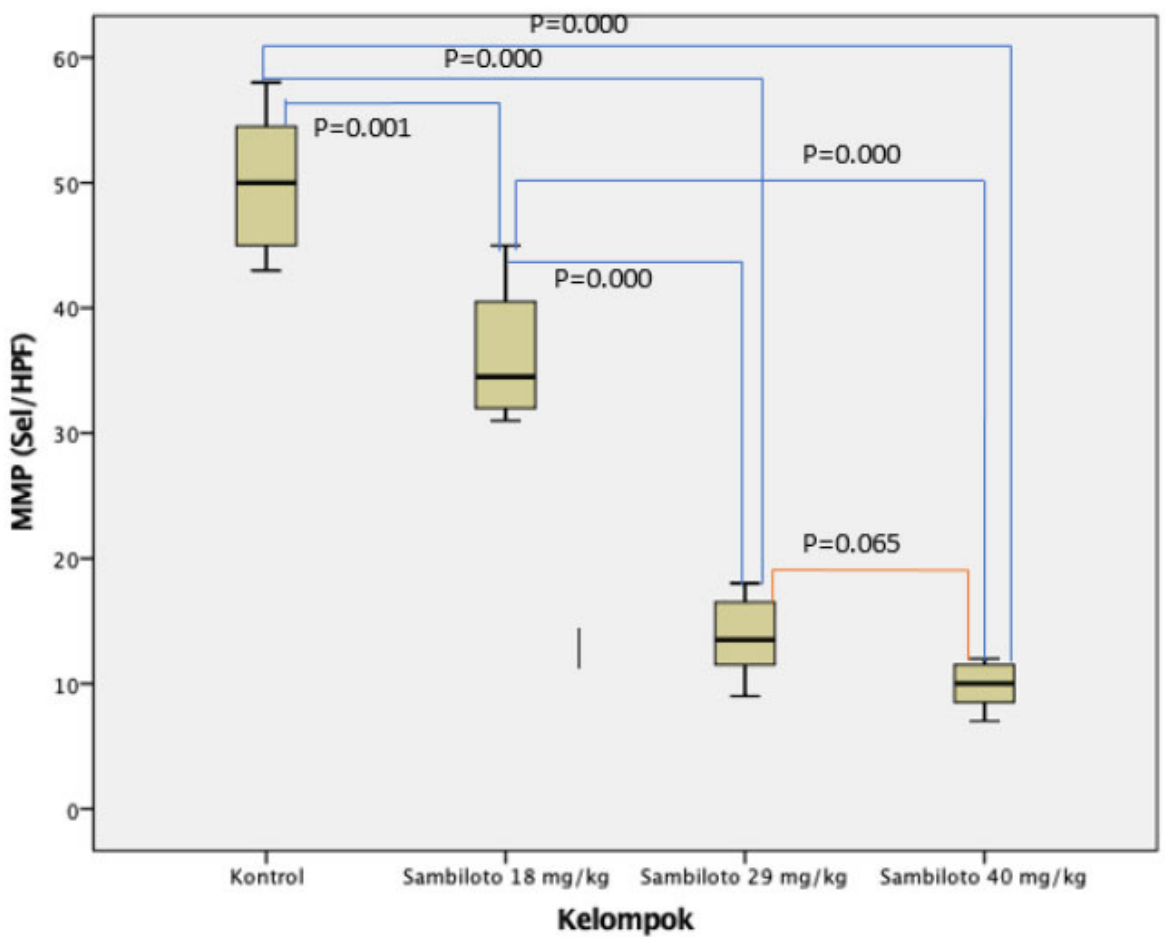

Grafik 1. Grafik Box Plot Perbandingan Rerata Ekspresi MMP-1 Pada MasingMasing Kelompok.

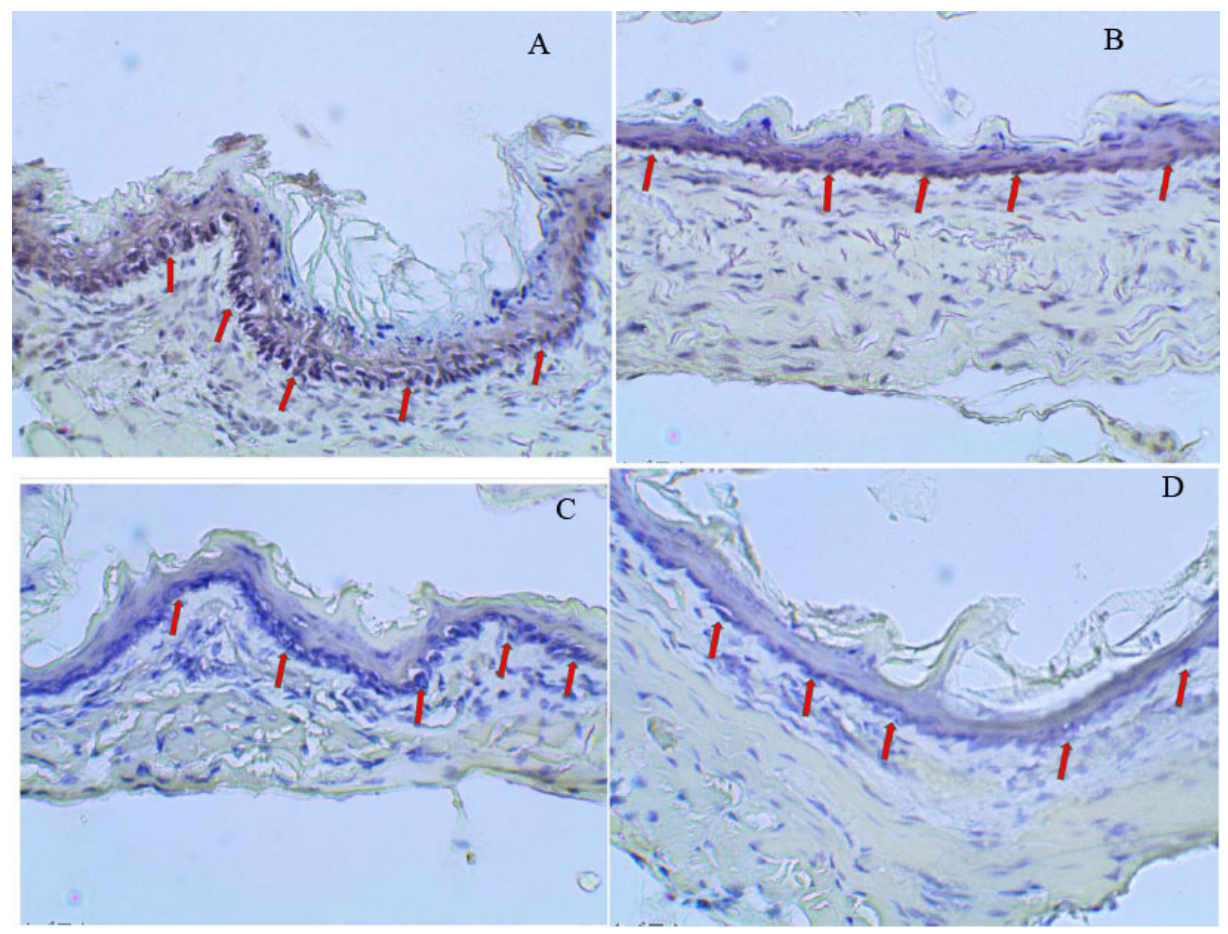

Gambar 1. Gambaran histologi yang menunjukkan ekspresi MMP-1 pada tunika intima aorta ascenden. A. Ekspresi MMP-1 pada kelompok kontrol, B. Ekspresi MMP-1 pada kelompok perlakuan 1, C. Ekspresi MMP-1 pada kelompok perlakuan 2, D. Ekspresi MMP-1 pada kelompok perlakuan 3.

(Dako EnVision ${ }^{\oplus}+$ Dual Link System-HRP $(\mathrm{DAB}+))$. Perhitungan jumlah ekspresi MMP-1 sediaan dilakukan dengan metode analisis digital dengan pembesaran lensa 


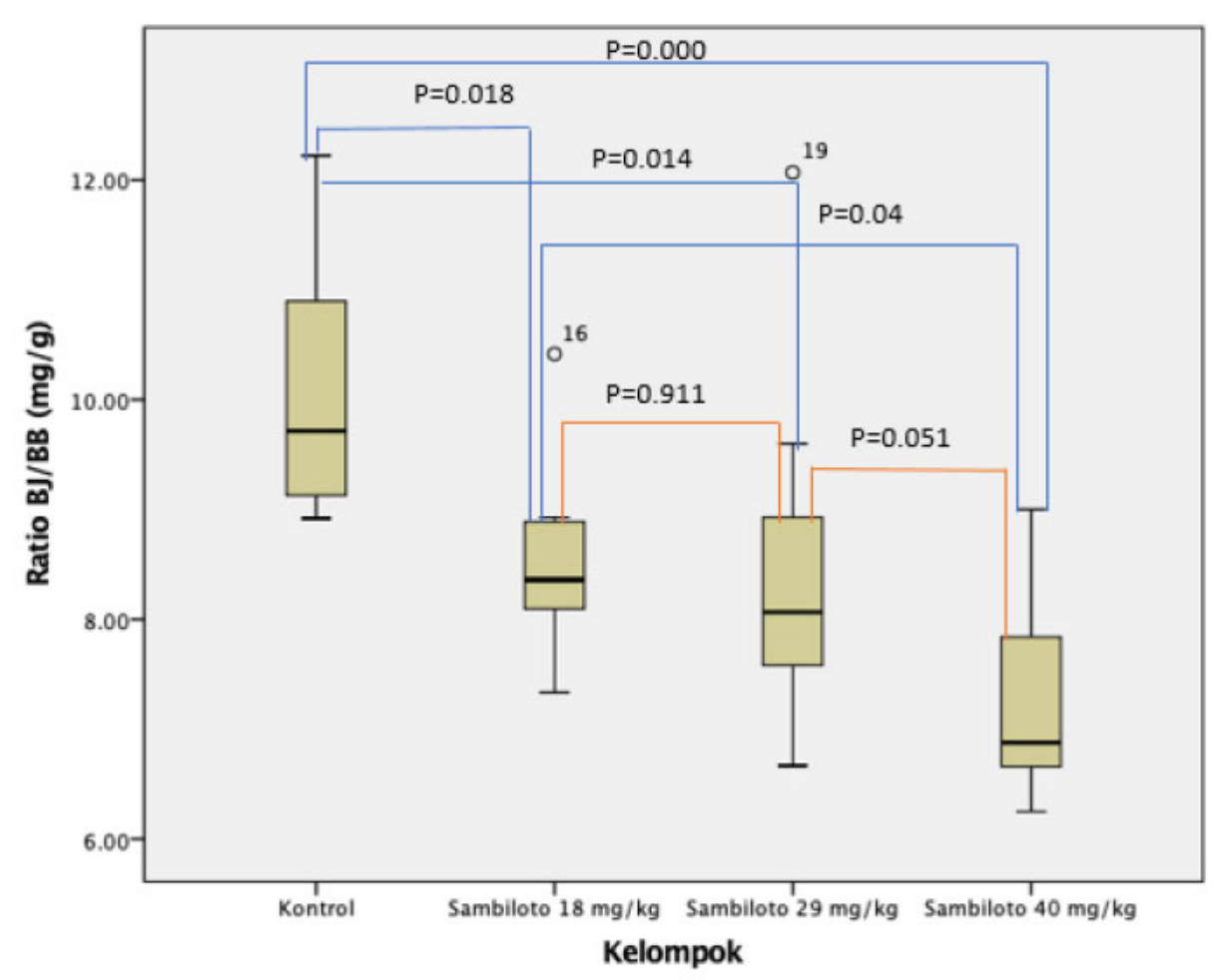

Grafik 2. Grafik Box Plot Rasio Berat Jantung/Berat Badan Mencit Pada MasingMasing Kelompok.

okuler 10 kali dan lensa objektif 40 kali, menggunakan mikroskop Olympus CX41 (Japan), difoto dengan kamera OptilabPro (Miconos, Indonesia). HRP akan berwarna coklat pada sitoplasma sel endotel yang menunjukkan ekspresi MMP-1 dan dihitung berdasarkan sel tunika intima yang mengekspresikan MMP-1. Kuantifikasi MMP-1 adalah jumlah sel di tunika intima aorta ascenden yang mengekspresikan MMP-1 dalam lapangan pandang dengan pembesaran total $400 \mathrm{x}$, dihitung masing-masing untuk satu lingkaran aorta. Hipertrofi jantung ditentukan dengan penghitungan rasio berat jantung (mg) dibagi berat badan mencit (gram).

\section{HASIL PENELITIAN}

Berdasarkan Post hoc analisis menggunakan Tamhane didapatkan perbedaan signifikan ekspresi MMP-1 antara kelompok kontrol dengan kelompok sambiloto $18 \mathrm{mg} / \mathrm{kg}$ (beda rerata $13,75 \mathrm{sel} /$ HPF $\{95 \%$ CI $5,56-21,94 ; \mathrm{P}=0.001\}$ ), sambiloto $29 \mathrm{mg} / \mathrm{kg}$ (beda rerata $36,25 \mathrm{sel} /$ HPF $\{95 \%$ CI 29,21 - 43,29; P = 0.000\}), dan sambiloto $40 \mathrm{mg} / \mathrm{kg}$ (beda rerata
40,12 sel/HPF $\{95 \%$ CI 33,25 - 47,00; P $=0.000\}$ ). Bila ditelaah antara kelompok perlakuan terdapat perbedaan signifikan antara kelompok sambiloto $18 \mathrm{mg} / \mathrm{kg}$ dengan sambiloto $29 \mathrm{mg} / \mathrm{kg}$ (beda rerata $22,50 \mathrm{sel} / \mathrm{HPF}$ \{95\% CI 15,61 - 29,39; P $=0.000\})$ dan antara kelompok sambiloto $18 \mathrm{mg} / \mathrm{kg}$ dengan sambiloto $40 \mathrm{mg} / \mathrm{kg}$ (beda rerata 26,37 sel/HPF \{95\% CI 19,68 - 33,07; P = 0.000\}). Dapat disimpulkan bahwa pemberian ekstrak sambiloto menurunkan ekspresi MMP-1 dengan kecenderungan efeknya meningkat dengan peningkatan dosis, dimana dosis optimal terdapat pada kelompok 2 yang diberikan ekstrak sambiloto dosis $29 \mathrm{mg} /$ kg BB (Grafik 1). Gambara ekspresi MMP1 secara imunohistokimia pada masingmasing kelompok dapat dilihat pada Gambar 1.

Berdasarkan Post hoc analisis menggunakan $L S D$ didapatkan perbedaan signifikan hipertrofi jantung berdasarkan rasio berat jantung/berat badan antara kelompok kontrol dengan kelompok sambiloto $18 \mathrm{mg} / \mathrm{kg}$ (beda rerata $1,52 \mathrm{mg} / \mathrm{g}$ $\{95 \%$ CI $0,28-2,76 ; \mathrm{P}=0.018\}$ ), sambiloto $29 \mathrm{mg} / \mathrm{kg}$ (beda rerata $1,59 \mathrm{mg} / \mathrm{g}\{95 \% \mathrm{CI}$ $0,35-2,83 ; \mathrm{P}=0.014\})$, dan sambiloto
$40 \mathrm{mg} / \mathrm{kg}$ (beda rerata 2,82 $\mathrm{mg} / \mathrm{g}\{95 \%$ CI $1,58-4,06 ; \mathrm{P}=0.000\}$ ). Bila ditelaah antara kelompok perlakuan terdapat perbedaan signifikan antara kelompok sambiloto $18 \mathrm{mg} / \mathrm{kg}$ dengan sambiloto $40 \mathrm{mg} / \mathrm{kg}$ (beda rerata $1,30 \mathrm{mg} / \mathrm{g}\{95 \%$ CI $0,06-2,54 ; \mathrm{P}=0.04\}$ ). Dapat disimpulkan bahwa perbedaan efek ekstrak sambiloto terhadap hipertrofi jantung baru muncul setelah dosis ditingkatkan menjadi $40 \mathrm{mg} /$ kg BB (Grafik 2).

\section{PEMBAHASAN}

Perkembangan plak aterosklerotik terjadi karena perubahan struktur yang menyebabkan akumulasi sel, matriks ekstraseluler, dan lipid dalam lapisan intima arteri. Peningkatan ekspresi dan aktivasi MMP berhubungan dengan perkembangan lesi arteri neointimal dan migrasi sel otot polos setelah terjadi cedera arteri, sedangkan inhibisi MMP menurunkan migrasi sel otot polos. Pada penelitian ini paparan asap rokok meningkatkan ekspresi MMP-1. Penelitian lain menunjukkan komponen rokok yaitu acrolein berkontribusi terhadap penyakit vaskular melalui peningkatan MMP-1 dan penurunan sekresi TIMP-3 pada endotel, sehingga menyebabkan angiogenesis, disrupsi matriks, dan cedera vaskular. ${ }^{5}$ Selain itu rokok juga dapat menginduksi ekspresi MMP-1 mRNA dan protein, dan meningkatkan aktivitas kolagenolitik sel saluran nafas manusia. ${ }^{9}$

Pada penelitian ini pemberian ekstrak sambiloto terbukti menurunkan ekspresi MMP-1 dengan kecenderungan efeknya meningkat dengan peningkatan dosis, dimana dosis optimal terdapat pada kelompok 2 yang diberikan ekstrak sambiloto dosis $29 \mathrm{mg} / \mathrm{kg}$ BB. Penelitian tentang efek ekstrak sambiloto terhadap ekspresi MMP mendapatkan hasil bahwa Andrographolide menurunkan ekspresi MMP-9 pada human monocytic THP-1 cells melalui mekanisme inhibisi NF-kB. ${ }^{10}$

Mekanisme ekstrak sambiloto dalam menurunkan ekspresi MMP-1 belum diketahui secara pasti. Walaupun demikian terdapat beberapa studi yang menunjukkan aktivitas antioksidan A. paniculata dan kandungannya yang berperan terhadap pencegahan aterosklerosis. Hal ini sesuai dengan penelitian Andrographolide yang 
dapat menurunkan ekspresi Monocyte Chemoattractant Protein-1 (MCP-1) pada stadium awal aterosklerosis. ${ }^{11}$ Studi in vitro juga mendapatkan hasil Andrographolide menurunkan proses aterosklerosis dengan menekan proinflamasi dan pembentukan foam cell yang dimediasi reactive oxygen species. ${ }^{12}$ Selain itu Andrographolide diketahui dapat menurunkan cedera stress oksidatif pada sel kultur RAW 264.7 yang diberikan ekstrak rokok melalui mekanisme inhibisi sinyal SIRT1/ERK.13 Penelitan lain juga membuktikan bahwa pemberian ekstrak sambiloto dapat menurunkan hipertrofi jantung dan apoptosis pada mencit yang diberikan makanan tinggi lemak. ${ }^{14}$

Pada penelitian ini pemberian paparan asap rokok selama 60 hari menyebabkan hipertrofi jantung pada semua kelompok. Hasil ini sesuai dengan penelitian lainnya yaitu pemberian asap rokok pada tikus dapat menginduksi terjadinya hipertrofi jantung, inflamasi dan cedera pembuluh darah. ${ }^{7}$ Nikotin juga terbukti menginduksi hipertrofi kardiomiosit pada kardiomiosit tikus Wistar melalui mekanisme TRPC3mediated $\mathrm{Ca}^{2+} / \mathrm{NFAT}$ signaling pathway. ${ }^{15}$

Pada penelitian ini pemberian ekstrak sambiloto dapat mengurangi hipertrofi jantung, dimana perbedaan efek baru muncul setelah dosis ditingkatkan menjadi $40 \mathrm{mg} / \mathrm{kg}$ BB. Pemberian ekstrak sambiloto belum mampu mencegah terjadinya hipertrofi jantung pada mencit yang diberikan paparan asap rokok, kemungkinan karena dosis dan durasi pemberian ekstrak sambiloto masih rendah.

Mekanisme ekstrak sambiloto terhadap pencegahan hipertrofi jantung belum diketahui secara pasti. Walaupun demikian terdapat penelitian tentang efek antioksidan terhadap pencegahan hipertrofi jantung yang dilakukan oleh $\mathrm{Al}$ Hariri dkk. dimana paparan asap rokok pada tikus menyebabkan hipertrofijantung dan pemberian antioksidan pomegranate (buah delima) 1 minggu sebelum paparan asap rokok sampai 4 minggu paparan rokok, dapat mencegah hipertrofi jantung pada kelompok perlakuan. Mekanisme yang berperan dalam pencegahan hipertrofi adalah efek antioksidan pomegranate yang dapat mengurangi proses inflamasi dan mencegah perubahan selular dan molekuler miokardium. ${ }^{7}$ Mekanisme yang sama mungkin juga berperan pada pemberian ekstrak sambiloto. Selain itu ekstrak sambiloto juga berperan menghambat pertumbuhan sel dan sintesis DNA. ${ }^{16}$

\section{SIMPULAN}

Terdapat perbedaan ekspresi MMP1 antara kelompok kontrol dengan kelompok sambiloto $18 \mathrm{mg} / \mathrm{kg}$, kelompok sambiloto $29 \mathrm{mg} / \mathrm{kg}$ dan kelompok sambiloto $40 \mathrm{mg} / \mathrm{kg}$. Pemberian ekstrak sambiloto menurunkan ekspresi MMP-1 dengan kecenderungan efeknya meningkat dengan peningkatan dosis, dimana dosis optimal terdapat pada kelompok 2 yang diberikan ekstrak sambiloto dosis $29 \mathrm{mg} /$ $\mathrm{kg}$ BB. Terdapat perbedaan hipertrofi jantung (rasio berat jantung/berat badan) antara kelompok kontrol dengan sambiloto $18 \mathrm{mg} / \mathrm{kg}$, kelompok sambiloto $29 \mathrm{mg} / \mathrm{kg}$ dan kelompok sambiloto 40 $\mathrm{mg} / \mathrm{kg}$. Perbedaan efek ekstrak sambiloto terhadap hipertrofi jantung baru muncul setelah dosis ditingkatkan menjadi $40 \mathrm{mg} /$ $\mathrm{kg}$ BB.

\section{ETIK PENELITIAN}

Penelitian ini telah mendapatkan ijin dari Komisi Etik Penelitian Fakultas Kedokteran Universitas Udayana/RSUP Sanglah Denpasar (no. 2020.02.1.0742).

\section{KONFLIK KEPENTINGAN}

Semua peneliti/penulis menyatakan penelitian ini bebas dari konflik kepentingan dan penulisan yang dilakukan secara mandiri tanpa ada pengaruh dari pihak ketiga.

\section{SUMBER PENDANAAN}

Studi ini tidak mendapatkan pendanaan dari pihak manaapun.

\section{KONTRIBUSI PENULIS}

AEP, INW, WA, GRW dan SYD menyusun ide dan rancangan penelitian. AEP dan KNA melaksanakan penelitian. AEP dan GRW bersama-sama menganalisis data. AEP menyusun draf manuskrip dan INW dan WA melakukan revisi. Semua penulis bersedia bertanggung jawab atas isi naskah.

\section{DAFTAR PUSTAKA}

1. Dunbar A, Gotsis W, Frishman W. Secondhand tobacco smoke and cardiovascular disease risk: an epidemiological review. Cardiol Rev. 2013;21(2):94-100. Available from: doi: 10.1097/CRD.0b013e31827362e4. PMID: 22968181 .

2. Erhardt L. Cigarette smoking: An undertreated risk factor for cardiovascular disease. Atherosclerosis. 2009;205(1):23-32. Available from: http://dx.doi.org/10.1016/j. atherosclerosis.2009.01.007

3. DiGiacomo SI, Jazayeri M-A, Barua RS, Ambrose JA. Environmental Tobacco Smoke and Cardiovascular Disease. Int J Environ Res Public Health. 2018;16(1):96. Available from: https://pubmed.ncbi.nlm.nih.gov/30602668

4. Fearon IM, Gaça MD, Nordskog BK. In vitro models for assessing the potential cardiovascular disease risk associated with cigarette smoking. Toxicol Vitr. 2013;27(1):513-22. Available from: http://dx.doi.org/10.1016/j.tiv.2012.08.018

5. Lemaître V, Dabo AJ, D’Armiento J. Cigarette smoke components induce matrix metalloproteinase-1 in aortic endothelial cells through inhibition of mTOR signaling. Toxicol Sci. 2011/07/08. 2011;123(2):542-9. Available from: https://pubmed.ncbi.nlm.nih. gov/21742783

6. F. Minicucci M, S. Azevedo P, F. Polegato B, A.R. Paiva S, A.M. Zornoff L. Cardiac Remodeling Induced by Smoking: Concepts, Relevance, and Potential Mechanisms. Inflamm Allergy-Drug Targets. 2012;11(6):442-7. Available from: http://dx.doi.org/10.2174/187152812803589958

7. Al Hariri M, Zibara K, Farhat W, Hashem Y, Soudani N, Al Ibrahim F, et al. Cigarette Smoking-Induced Cardiac Hypertrophy, Vascular Inflammation and Injury Are Attenuated by Antioxidant Supplementation in an Animal Model. Front Pharmacol. 2016;7:397. Available from: https://pubmed.ncbi.nlm.nih. gov/27881962

8. Warditiani NK, Susanti NMP, Arisanti CIS, Putri NPRD, Wirasuta IMAG. Antidyslipidemia and antioxidant activity of andrographolide compound from sambiloto (andrographis paniculata) herb. Int J Pharm Pharm Sci. 2017;9(7):59. Available from: http://dx.doi. org/10.22159/ijpps.2017v9i7.18109

9. Mercer BA, Kolesnikova N, Sonett J, D’Armiento J. Extracellular Regulated Kinase/Mitogen Activated Protein Kinase Is Up-regulated in Pulmonary Emphysema and Mediates Matrix Metalloproteinase-1 Induction by Cigarette Smoke. J Biol Chem. 2004;279(17):17690-6. Available from: http://dx.doi.org/10.1074/jbc. m313842200

10. Lee W-R, Chung C-L, Hsiao C-J, Chou Y-C, Hsueh P-J, Yang P-C, et al. Suppression of matrix metalloproteinase- 9 expression by andrographolide in human monocytic THP1 cells via inhibition of NF- $\kappa \mathrm{B}$ activation. Phytomedicine. 2012;19(3-4):270-7. Available from: http://dx.doi.org/10.1016/j. phymed.2011.11.012

11. Yulis Hamidy M, Oenzil F, Yanwirasti Y, Aldi Y. Effect of Andrographolide on Monocyte 
Chemoattractant Protein-1 Expression at the Initiation Stage of Atherosclerosis in Atherogenic Diet-Fed Rats. Biomed Pharmacol J. 2019;12(3):1167-73. Available from: http:// dx.doi.org/10.13005/bpj/1745

12. Wu T, Peng Y, Yan S, Li N, Chen Y, Lan T. Andrographolide Ameliorates Atherosclerosis by Suppressing Pro-Inflammation and ROS Generation-Mediated Foam Cell Formation. Inflammation. 2018;41(5):1681-9. Available from: http://dx.doi.org/10.1007/s10753-0180812-9

13. Zhang X, Ding M, Cheng C, Zhang Y, Xiang $\mathrm{S}$, Lu J, et al. Andrographolide attenuates oxidative stress injury in cigarette smoke extract exposed macrophages through inhibiting SIRT1/ERK signaling. Int Immunopharmacol. 2020;81:106230. Available from: http://dx.doi. org/10.1016/j.intimp.2020.106230

14. Hsieh Y-L, Shibu MA, Lii C-K, Viswanadha VP, Lin Y-L, Lai C-H, et al. Andrographis paniculata extract attenuates pathological cardiac hypertrophy and apoptosis in high-fat diet fed mice. J Ethnopharmacol. 2016;192:1707. Available from: http://dx.doi.org/10.1016/j. jep.2016.07.018

15. Li N, Si B, Ju J-F, Zhu M, You F, Wang D, et al. Nicotine Induces Cardiomyocyte Hypertrophy Through TRPC3-Mediated Ca2+/ NFAT Signalling Pathway. Can J Cardiol. 2016;32(10):1260.e1-1260.e10. Available from: http://dx.doi.org/10.1016/j.cjca.2015.12.015

16. Hossain MS, Urbi Z, Sule A, Hafizur Rahman KM. Andrographis paniculata (Burm. f.) Wall. ex Nees: a review of ethnobotany, phytochemistry, and pharmacology. ScientificWorldJournal. 2014/12/24. 2014;2014:274905. Available from: https://pubmed.ncbi.nlm.nih.gov/25950015

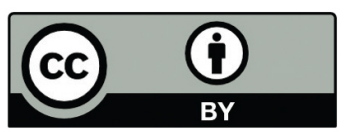

This work is licensed under a Creative Commons Attribution 